\title{
A Study of Consumers' Complaints against Real Estate Agents in Lagos Metropolis, Nigeria
}

\author{
ARALOYIN Funmilayo Moyinola \\ Department of Estate Management \\ Obafemi Awolowo University, Ile-Ife \\ Osun State, Nigeria
}

\begin{abstract}
The study examined consumers' complaints against real estate agents in Lagos Metropolis, Nigeria with a view to providing information that could ensure effective service orientation and high consumers' satisfaction. Data were elicited from real estate agents and consumers in the study area through self-administered questionnaire and analyzed with the use of frequency distribution, percentages and mean rating. The study found some level of dissatisfaction as $35.3 \%$ representing 61 of the real estate agency consumers were dissatisfied with real estate agency related services. $30.1 \%$ of the respondents objected to the possibility of repeat business with their real estate agent while $33 \%$ rejected the possibility of recommending their agents to others. The most common complaint against real estate agents was 'fee levels too high' as reported by 81 respondents representing $31 \%$ of the study population. The study also revealed that real estate agency consumers complained about communication problems, over pricing of property, agents providing wrong information, agents not delivering what was required, agents pressurizing customers, delays, deadlines not met, galumphing, agents providing wrong information, mismanagement of the property in their care etc. Therefore real estate service consumers' complaints must be thoroughly attended to as these may lead to consumers' dissatisfaction. Real estate agents must ensure that customer service remains high so as to experience consumers' satisfaction, retention and successful businesses.
\end{abstract}

Keywords: Consumers' Complaints, Real Estate Agents, Nigeria

DOI: $10.7176 /$ CER/13-4-05

Publication date:July $30^{\text {th }} 2021$

\section{Introduction}

Consumer complaints have been defined as an expression of dissatisfaction to a responsible party on consumers' behalf. It also refers to an act of expressing discontent or unhappiness about a situation. Complaints are reasons for not being satisfied. Consumer complaints are usually informal concerns directly addressed to a service provider or producer, and most consumers try to resolve problems with products and services in this way, but it sometimes requires persistence. Gallagher (2011) urged business consultants to view consumer complaints as a gift because they can give valuable information for improved products and services. Consumer complaint however if not properly handled can lead to consumer dissatisfaction. Consumer dissatisfaction can be defined as a state or attitude of displeasure and discontent. A dissatisfied consumer is one whose expectations or anticipations have not been met by the producer. Consumer satisfaction/dissatisfaction can be measured by the degree of disparity between expectations and perceived product performance. Studies on consumer dissatisfaction or otherwise are of significant importance as consumer satisfaction has been so highly publicized as a successful business determinant.

Estate agency is a sector widely associated with levels of consumer dissatisfaction. Real estate agent plays a pivotal role in the sale, purchase or letting of landed properties. They market property, draw up contract for sale or purchase, provide advice which many client may rely upon and which may influence their decisions. Past studies have shown that clients are dissatisfied with services rendered by their estate agent (Miceli et al 2000, Crews, 2002; Araloyin, 2010; Araloyin and Ojo, 2011). The key objective in this study is to identify sources of complaints against real estate agents and to provide information on what factors influence consumers' satisfaction in real estate agency. Studies on consumers' complaints would help in customers' satisfaction and retention. It would also help to attract qualified customers and improve service delivery in real estate agency. It was reasoned that this study would be of interest to real estate firms who provide agency related services and also real estate consumers as it would assist in bridging the gap between service expectations and actual performance.

\section{Literature Review}

An agency relationship arises for practical reasons, since a single individual cannot know everything and cannot be everywhere. Without the concept of agency, many everyday activities would be impossible. Gunasekara (1995) noted that if not for the concept of agency, and its recognition in law, every party to a contract would have to be personally and directly involved in making and carrying out the business transaction. According to Eisenhardt (1989), the law of agency is among the most fundamental because majority of the world's work are done by person 
acting as representative of another person. The theory is applicable in different fields like accounting, economics, finance, marketing, political science, sociology etc. Luxford's Real Estate Agency (1979) asserted that "a real estate agency is an agency of a somewhat specialized and limited nature". Nonetheless real estate agents are subject to all the normal features of agency law, such as performance and fiduciary duties owed by the agent to the principal, and the principal's right to compensate the agent.

Past studies have also shown that real estate practice are not meeting the needs of the parties involved in a real estate purchase and sales transaction (Guntermann and Smith, 1988; Haag, Rutherford and Thomson, 2000; Pancak and Sirmans, 2008; Araloyin, 2010; Araloyin and Ojo, 2011). The expectations and perceptions of buyers and sellers are often at variance with actual service performance of the real estate agents. These have led to complaints against real estate agents.

According to Goodman (1999) on average, across all industries, 50\% of consumers will complain about a problem to a front line person. In business to business environments, $75 \%$ of customers will complain to a front line person. The rate of complaint varies depending on the type of problem. The study of consumer complaint behaviour is important from both a marketing assessment and a social welfare point of view (Goodman, 1995). Consumer complaints constitute an important feedback device for companies to assess consumer satisfaction with their services and products. In a situation where a dissatisfied consumer refuses to complain, management are denied of these feedbacks. Such a consumer may decide not to buy the product/service again or warn family and friends to avoid it, which can be costly to the provider. Without knowledge of the sources of dissatisfaction, companies will be unable to change its techniques. From a social welfare perspective, it becomes important to study remedial action seeking behaviour of dissatisfied customer groups. Such findings are necessary in the formulation of effective consumer protection legislations programs.

According to Anderson et al (1994), the number of complaints filed against a salesperson measured service quality. In other words, the fewer the complaints, the higher is the assumed service quality. Shilling and Sirmans (1988) defined quality as the number of complaints against real estate per state. The authors found that licensing increases the quality of service, but produces anti-competitive side effects. Johnson and Loucks (1986) defined quality as the complaint rate per transaction. The authors found that licensing requirements increase service and improves the effectiveness of the real estate agency. The authors found that the rate of complaints reduced when there were fewer licensees per capital.

Guntermann and Smith (1988) relate complaints against real estate agents to enforcement and compliance efforts by regulators and pre-licensing education prerequisites. Emphasis was based on the presumption that if agents know what to do, then the quality of service performed will be improved. According to the authors, agents often know what is correct in a given situation but may not do it since doing so is not always in the agent's self-interest. The authors found that minimal levels of education and training reduce complaints, but additional education provides decreasing returns. The findings of the study suggested that the most effective way to reduce consumers' complaints is through vigorous efforts at enforcement and compliance with education and licensing requirements.

A study by Miceli et al (2000) revealed that representation of both buyers and sellers has create a dilemma when both parties were represented by the same firm, a conflict of interest known as dual agency occurred. A real estate agent when acting as a dual agent cannot fully satisfy the duties of loyalty, full disclosure, and obedience to lawful instructions which are required obligation of the estate agent to clients.

Fornell (1992) investigated into customer satisfaction. The study revealed that customer satisfaction has a direct impact on the primary source of future revenue streams for most companies. According to the author, when quality is recognized by the buyer, it is reflected in customer satisfaction. Products and services that provide high customer satisfaction are less vulnerable to competition. They have a higher proportion of repeat business and higher gross margins. In an effort to promote quality and increase customer orientation within its industries, Sweden has developed a new economic indicator, the Customer Satisfaction. The author also noted that satisfied customers are an asset to the firm. Changes in satisfaction are consequences of past decisions and predictors of future performance. The ultimate judgment of quality is with the customer. Quality improvements that are not recognized by the customer are questionable investments. Accordingly, the most meaningful measurement of quality is how it affects customer satisfaction.

Day and Landon (1977) outlined the steps toward the development of a theory of consumer complaint behaviour. Though their conceptualization delineates circumstances leading to consumer dissatisfaction, a broad typology of complaint behaviour, factors influencing complaint behaviour and a preliminary decision model of complaint 
behaviour, no empirical evidence is cited to substantiate their theoretical framework. Landon (1977) has proposed a model of consumer complaint behaviour where the major explanatory variables suggested are: dissatisfaction, importance, benefit from complaining, and personality. His formulation, however, remains largely theoretical.

Aderibigbe (2004) identified four problems associated with estate agency practice. These problems are: activities of quacks; dysfunctional property design; attitude of landlord; lack of awareness. He defined a quack as any person who has not undergo a period of training in the field of estate management or land economy, has not passed the prescribed examination of the Nigerian Institution of Estate Surveyors and Valuers and has not been registered as a fit and proper person to practice the profession of Estate agent in accordance with decree No. 24 of 1975 . A lot of quacks participate in the market as agents and these people most of the time do things which are not professional.

Viikari (2017) studied the construct of relationship quality in the field of real estate between real estate agents and property owners. The results indicate that the outcome of relationship quality is customer loyalty, while satisfaction and trust are dimensions of quality relationship. Therefore, to manage quality relationship and create customer loyalty, real estate agencies should seek to increase consumer trust and satisfaction through quality service, expertise and relational selling behavior.

This study therefore assessed consumers' complaints in the real estate agency market in Lagos metropolis using some of the variables identified in existing literature with a view to improving service orientation and providing high consumers' satisfaction.

\section{The Study Area}

This research work was conducted in Lagos Metropolis. The choice of the metropolitan Lagos was as a result of the large volume of economic and commercial activities taken place in these locations which exceeds that of all capitals or towns in the country. Also, a greater percentage of estate surveying and valuation firms involved in real estate agency practice have their head offices or branch offices located in the metropolitan Lagos. The membership directory of the Nigerian Institution of Estate Surveyors and Valuers (2013 edition) showed that approximately $54 \%$ of estate surveying firms in Nigeria are based in Lagos metropolis. The Metropolitan Lagos most often refers to the urban area, which includes both the islands of Lagos and the mainland suburbs. Lagos Island plays host to the main government buildings, shops and offices. It includes Victoria Island, Ikoyi, Apapa, Ikeja GRA, etc. The mainland part of the state had developed and still developing rapidly and approaching an eventual merger with the more distant part of the mainland including Epe, Ikorodu and Badagry. The more developed mainland and Lagos Island makeup the Metropolitan Lagos.

\section{Research Methodology}

The study population for this study comprised estate surveying and valuation firms and their customers in Lagos metropolis. The study sampled 100 estate surveying and valuation firms in the study area representing about $30 \%$ of the sample frame for manageability. Two (2) service consumers were randomly selected from each estate surveying and valuation firm, given a total of 200 service consumers. The data for this study were derived from primary and secondary sources. The primary data were obtained through the use of structured questionnaire. Secondary data for the study were sourced from journals, text books, seminar/conference papers and NIEVS directory.

Issues addressed in the questionnaires include socio economic characteristics of the respondents such as age, sex, academic qualification professional qualification, marital status and occupation. Other questions focused on the sources of consumers' complaints and levels of consumers' satisfaction in real estate agency. Simple random sampling technique was adopted to obtain the actual sampled respondents. Data were generated with the aid of a five-point Likert scale questionnaire administered on Estate Surveyors and Valuers and their customers. Tables of frequencies and percentages were used to present the results obtained.

\section{Data Analysis and Findings}

A total number of 300 questionnaires were administered (100 Estate Surveyors and 200 real estate agency service consumers). 261 questionnaires were returned and found usable. 88 estate surveyors and 173 service consumers made up the sample. This represented $87 \%$ response rate which is a fair representation for the study analysis.

Table 1 presented the socio economic characteristics of the estate surveyors. There were 88 of them in the sample. The average age of the estate surveyors was between the ages of 36 - 50 years old and had an average length of nine (9) years' experience. The average age of the estate surveying firm to which the agents belong was ten (10) years. There are several aspects of estate surveying such as valuation, consultancy, property management, project management, real estate agency etc. However, emphasis was placed on estate surveyors practicing as real estate agents. Majority of the estate surveyors have Bachelor of Science (B.Sc) as their minimum qualification (61.1\%). 
The estate surveyors were unevenly divided between male $(71.1 \%)$ and female $(28.9 \%)$. The relatively large number of male agents is not unexpected considering the strenuous nature of the work. The responses show that the largest count of $65.6 \%$ represents those that are Associate members of the Nigerian Institution of Estate Surveyors and Valuers (NIEVS), a substantial 18.9\% represents those that are probationers under NIEVS while the lowest count $(12.2 \%)$ represents the Fellows (FNIVS). The above results showed that most of the respondents are experienced and can be relied upon to give adequate data on the study.

Table 1

Socioeconomic Characteristics of Estate Surveyors

Estate Surveyors (88)

Age
Education
Professional
Qualification

Sex

Age of Firm

Year of Experience

Status of Respondent

$\begin{array}{cl}<35 & 41.1 \% \\ 36-50 & 50.0 \% \\ >50 & 8.9 \%\end{array}$

Graduate Degree

$61.1 \%$

Masters Degree

$33.3 \%$

Others

$5.5 \%$

FNIVS

$12.2 \%$

$65.6 \%$

$18.9 \%$

Probationer

$3.3 \%$

Others

$71.1 \%$

Male

$28.9 \%$

Female

10 years

Mean Age

9 years

Average

$14.4 \%$

Managing Partner

$35.6 \%$

Partner

$22.2 \%$

Associate

$14.4 \%$

Manager

$13.4 \%$

The sample characteristics for real estate service consumers are shown in Table 2. There were 173 real estate service consumers in the sample. The consumers consist of $77.3 \%$ male and $22.7 \%$ female. The average consumer was between the ages of $36-50$ years old and had an average annual income of over N1,000,000. 56.3\% of real estate consumers were married, $38.8 \%$ single and the remaining 4.9 divorced. The 173 consumers that were surveyed had an average length of 10 years' experience in real estate related businesses. Majority of the consumers were self-employed representing $56.2 \%$ of the sample and have a graduate degree as the highest level of education attained (47.2\%). From this outcome, it could be deduced that most of the consumers are qualified to know the importance of research and can be relied upon to give credible information. Therefore the reliability of the data is sustained and the information obtained actually reflects the view of real estate service consumers on the subject under study. 
Table 2

Sample Characteristics for Real Estate Service Consumers

\begin{tabular}{|c|c|c|}
\hline & \multicolumn{2}{|c|}{ Real Estate Service Consumers (173) } \\
\hline Age & $\begin{array}{l}<35 \\
36-50 \\
>50\end{array}$ & $\begin{array}{c}34.0 \% \\
59.1 \% \\
6.9 \%\end{array}$ \\
\hline Education & $\begin{array}{l}\text { Graduate Degree } \\
\text { Masters Degree } \\
\text { Others }\end{array}$ & $\begin{array}{l}47.2 \% \\
37.9 \% \\
14.8 \%\end{array}$ \\
\hline $\begin{array}{l}\text { Sex } \\
\text { Year of Experience }\end{array}$ & $\begin{array}{l}\text { Male } \\
\text { Female } \\
\text { Mean }\end{array}$ & $\begin{array}{l}77.3 \% \\
22.7 \% \\
10 y e a r s\end{array}$ \\
\hline Marital Status & $\begin{array}{l}\text { Married } \\
\text { Single } \\
\text { Divorced }\end{array}$ & $\begin{array}{c}56.3 \% \\
38.8 \% \\
4.9 \%\end{array}$ \\
\hline Occupation & $\begin{array}{l}\text { Civil Servant } \\
\text { Self Employed } \\
\text { Others }\end{array}$ & $\begin{array}{r}34.5 \% \\
56.2 \% \\
9.3 \%\end{array}$ \\
\hline Annual Income & $\begin{array}{l}<\mathrm{N500,000} \\
\text { N500,000-N1,000,000 } \\
>\mathrm{N} 1,000,000\end{array}$ & $\begin{array}{l}25.6 \% \\
22.7 \% \\
51.7 \%\end{array}$ \\
\hline
\end{tabular}

Table 3 revealed some complaints against estate surveyors practicing as real estate agents. $36.4 \%$ of the respondents reported that their agents did not deliver what was required. This was the major source of dissatisfaction as 63 respondents attested to this fact. The second major complaint was fee levels too high as rated by 56 respondents representing $32.4 \%$ of the sample. Delays, deadlines not met had the third position scoring $15.0 \%$ (26 responses). Communication problems had 9.3\% responses and lastly $6.4 \%$ went for lack of technical skills as a source of complaint in real estate agency service delivery.

These results were compared to the real estate agents' responses in which $28.4 \%$ felt the main cause of complaint was fee levels too high which took the second position in the consumers' responses. $27.3 \%$ believed that communication problems is the major source of complaint, $18.2 \%$ were of the opinion that there were delays in service delivery and deadlines are often not met and $6.8 \%$ chose the absence of technical skills in estate agents as a source of complaint. No opinion and no complaint scored $2.3 \%$ each.

The study concluded that the major source of complaint in real estate agency, both from the clients and agents perspective were "fees too high" and "agents not delivering what was required". Since agency fee is fixed, that is $10 \%$ of the contract sum, the issue of fees too high as a major source of complaint should not arise. It was however reasoned that some real estate agent might be charging more than the expected fee or collecting double fees (from the buyer and the seller) which is not supposed to be. Some real estate consumers argued that agency fee should reflect agent's expenses and not just a fixed percentage of the contract sum.

The other complaint, "agents not delivering what was required", might be due to the inelasticity of the real estate market. As it is well known that the physical supply of property is virtually fixed and the mix of land uses is also somewhat fixed due to planning controls. Moreover, it is difficult for property development to respond to increases in demand because of the time taken to obtain permission to build, arrange finance, construct buildings and sell/let the property. At the same time, it is difficult for supply to respond to decreases in demand because it is not always feasible or viable to demolish buildings. "Agents not delivering what was required", might also be due to the fact that some clients/customers expect too much from their real estate agents. Some even form expectations which are not realistic. Political or economic conditions beyond the control of the estate agents might also contribute to this problem. 
Table 3

Real Estate Service Complaints

\begin{tabular}{|c|c|c|c|c|}
\hline Complaints & rs (173) & Given by Agents (88) & Agg & te $(261)$ \\
\hline Communication Problems & $9.3 \%($ & $27.3 \%$ & $\overline{(24)}$ & $15.3 \%(40)$ \\
\hline Fee Levels too high & $32.4 \%($ & $28.4 \%$ & (25) & $31.0 \%(81)$ \\
\hline Delays, Deadlines not met & $15.0 \%($ & $18.2 \%$ & (16) & $16.1 \%(42)$ \\
\hline Did not deliver what was required & $36.4 \%($ & $14.8 \%$ & (13) & $29.1 \%(76)$ \\
\hline No Technical Skills & $6.4 \%($ & $6.8 \%$ & $(06)$ & $6.5 \%(17)$ \\
\hline Others & $0.6 \%($ & $2.3 \%$ & (02) & $1.1 \%(03)$ \\
\hline No Complaints & $0.0 \%($ & $2.3 \%$ & (02) & $0.8 \%(02)$ \\
\hline
\end{tabular}

The consumers reported of communication problem between them and their real estate agents during the transaction period. This is a very vital area that should not be ignored in order to get more satisfied clients. Communication plays a major role in influencing consumer purchases in new product or services. It plays both informative and a persuasive role over the life cycle of goods and services. Frequent communicating with customers enables one to deliver message to them so that they will react to it. This communication adds to the agent's value in the mind of the consumer and builds on their cognitive and emotional ties to the agent. Consumers needed to be informed of special efforts that are done for them behind the scenes to assure quality. According to Napper (2013), good communication between the estate agent and landlords or tenants is a vital tool in keeping customers happy and retaining them.

The result showed that there are delays in transaction periods and deadlines not always met. Delays in transactions could be due to several reasons beyond the control of the real estate agent, such as financial reasons, economic crisis, political instability, insufficient information, real estate title issues etc. Promising more than the agent can deliver could lead to delays and lower perception of quality when the promises are not fulfilled.

The study also revealed that "no technical skills" was a reason for complaint against real estate agents. There are some important skills a real estate agent must possess which include sales and marketing principles, active listening, knowledge of laws, negotiation and persuasion skills, coordination, critical thinking, time management, reading comprehension, active learning, government regulations etc. The study found that real estate agency in Nigeria is practiced by other professionals who are not Estate Surveyors and Valuers such as lawyers, planners, engineers and even people without formal training in any discipline. The complaint about technical skills could be traced to this group of people without formal training in any discipline.

The study revealed some other complaints against real estate agents. These include agents not revealing known property faults; agents pressurizing customers, over exaggerated property descriptions, over pricing of property, gazumping, agents providing wrong information, mismanagement of the property in their care etc.

Table 4

Real Estate Consumers' Level of Satisfaction/Dissatisfaction

\begin{tabular}{lccc}
\hline & No & Undecided & Yes \\
Possibility of repeat business & $30.1 \%(52)$ & $11.6 \%(20)$ & $58.4 \%(101)$ \\
$\begin{array}{l}\text { Possibility of recommending } \\
\text { Agents to others }\end{array}$ & $33.0 \%(57)$ & $13.3 \%(23)$ & $53.8 \%(93)$ \\
\hline
\end{tabular}

The result in table 4 clearly suggested that majority of the clients representing $58.4 \%$ would like to carry out repeat businesses with their real estate agent and also recommend them to their friends or relatives (53.8\%). This indicated that the consumers were to some extent satisfied with the performance of their real estate agents. However, 30.1\% (52) of real estate consumers are not interested in carrying out repeat business with their agents and 33\% (57) would not recommend their agent to their friends or relatives indicating some level of consumers' dissatisfaction.

The consumers were asked to rate their overall satisfaction with the services provided by their agent on a 7 point likert scale. The results were condensed as shown in Table 5. 
Table 5

Consumers' Overall Satisfaction

\begin{tabular}{|c|c|c|c|}
\hline $\begin{array}{l}\text { Clients' Overall } \\
\text { Satisfaction }\end{array}$ & $\begin{array}{l}\text { Dissatisfied } \\
35.3 \%(61)\end{array}$ & $\begin{array}{l}\text { Neutral } \\
22.0 \%(38)\end{array}$ & $\begin{array}{l}\text { Satisfied } \\
\qquad 42.8 \%(74)\end{array}$ \\
\hline
\end{tabular}

Table 5 revealed that $42.8 \%$ (74) of the respondents were satisfied with the services provided by their agents while $35.3 \%$ representing 61 of the respondents were dissatisfied with real estate related services. It was reasoned that the real estate agents need to improve their quality of service to get more delighted customers.

\section{Conclusion}

The study investigated into real estate agency and found consumers' complaints against real estate agents. Among these complaints are communication problems, fee levels too high, over pricing of property, agents providing wrong information, agents not delivering what was required, agents pressurizing customers, delays, deadlines not met, gazumping, agents providing wrong information, mismanagement of the property in their care etc.

Considering the distinguishing characteristics of real estate, estate agents should really be available to assist their customers in making one of their life's most important decision. Real estate agents should make service delivery pain free and seamless as possible, not hindering or causing further difficulties. Real estate agents need to pay more attention to clients' needs and adjust their businesses accordingly. Also, real estate service consumers need to be mindful of why some estate agents do not give them the service levels they desire and the reasons responsible for this. Therefore the choice of whom to handle ones most important asset is an important one.

\section{References}

Anderson, E.W., Fornell, C. and Lehmann, D.R. (1994). Customer Satisfaction, Market Share and Profitability: Findings from Sweden, Journal of Marketing, 58(3), 53-66

Araloyin, F.M., (2010): A Study of Service Quality in Real Estate Agency in Lagos Metropolis, Unpublished M.Sc. Dissertation Submitted to the Department of Estate Management, Obafemi Awolowo University, Ile-Ife.

Araloyin, F. M. and Ojo, O. (2011). Factors Affecting the Provision of Quality Service in Real Estate Agency in Lagos Metropolis, Nigeria. International Journal of Business Administration, 2 (1): 71 - 79

Araloyin, F. M. and Ojo, O. (2011). Factors Influencing the Selection of Real Estate Agents in Lagos Metropolis, Nigeria. British Journal of Management and Economics, 1 (1): 33 - 41

Day, R.L. and Landon, E.L. (1977). Towards a Theory of Consumer Complaining Behaviour. In Consumer and Industrial Buying Behaviour (ed. By A.G. Woodside, I.N. Sheth and P.D. Bennet, 229-242, NorthHolland, New York

Eisenhardt, K.M. (1989). Agency Theory: An Assessment and Review, Academy of Management Journal, 14 (1): 57-74.

Fornell, C. (1992). A National Customer Satisfaction Barometer: The Swedish Experience, Journal of Marketing, American Marketing Association, 56 (1): 6-21

Gallagher, B.J. (2011). A Customer Complaint is a Gift, Huffingtonpost.com, Retrieved August 8, 2017

Goodman, J. (1999). Basic Facts on Customer Complaint Behavior and the Impact of Service on the Bottom Line in Competitive Advantage, 1-5

Guntermann, K.L. and Smith, R.L. (1988). Licensing Requirements, Enforcement Effort and Complaints against Real Estate Agents, Journal of Real Estate Research, 3 (2): 11-20.

Haag, J.T., Rutherford, R.C. and Thomson, T.A. (2000). Real Estate Agents Remarks: Help or Hype? Journal of Real Estate Research, 20 (1/2): 205-215.

Johnson, L.L. and Loucks, C. (1986). The Effect of State Licensing Regulations on the Real Estate Brokerage Industry, Journal of the American Real Estate and Urban Economics Association, 14 (4): 567-82.

Landon, E.L. (1977). A Model of Consumer Complaint Behaviour, in R.L. Day (ed.). Consumer Satisfaction, Dissatisfaction and Complaining Behaviour, Bloomington Indiana: School of Business, Indiana University

Miceli, T.J., Pancak, K.A. and Sirmans, C.F. (2000). Restructuring Agency Relationships in the Real Estate Brokerage Industry: An Economic Analysis, Journal of Real Estate Research, 20 (1/2): 31-47.

Napper, C. (2013). Management of Communication, https://rentview.com/blog/author/colin napper/, Retrieved August 8, 2017

NIESV (2013): Directory of Estate Surveyors and Valuers, Nigerian Institution of Estate Surveyors and Valuers, Lagos. 
Pancak, K.A. and Sirmans, C. (2008). Agency Content on Licensing Exams: Assessing Professional Competency, Journal of Real Estate Practice and Education, 11 (1): 3-16

Shilling, J.D. and Sirmans, C.F. (1988). The Effects of Occupational Licensing on Complaints against Real Estate Agents, Journal of Real Estate Research, 3 (2): 1-9.

Viikari, V. (2017). Effects of Relationshipship Quality Between Estate Agents and Sellers in the Real Estate Market. Bachelor's Thesis Submitted to Aalto University, School of Business, Mikkeli Campus. 